\title{
Novel enterocin E20c purified from Enterococcus hirae 20c synergised with B-lactams and ciprofloxacin against Salmonella enterica
}

\author{
Preeti Sharma, Muzamil Rashid and Sukhraj Kaur *i)
}

\begin{abstract}
Background: An increasing rate of antibiotic resistance among Gram-negative bacterial pathogens has created an urgent need to discover novel therapeutic agents to combat infectious diseases. Use of bacteriocins as therapeutic agents has immense potential due to their high potency and mode of action different from that of conventional antibiotics.
\end{abstract}

Results: In this study, a novel bacteriocin E20c of molecular weight $6.5 \mathrm{kDa}$ was purified and characterized from the probiotic strain of Enterococcus hirae. E20c had bactericidal activities against several multidrug resistant (MDR) Gramnegative bacterial pathogens. Flow cytometry and scanning electron microscopy studies showed that it killed the Salmonella enterica cells by forming ion-permeable channels in the cell membrane leading to enhanced cell membrane permeability. Further, checkerboard titrations showed that E20c had synergistic interaction with antibiotics such as ampicillin, penicillin, ceftriaxone, and ciprofloxacin against a ciprofloxacin- and penicillin-resistant strain of S. enterica.

Conclusion: Thus, this study shows the broad spectrum antimicrobial activity of novel enterocin E20c against various MDR pathogens. Further, it highlights the importance of bacteriocins in lowering the minimum inhibitory concentrations of conventional antibiotics when used in combination.

Keywords: Bacteriocin, Lactic acid bacteria, Antimicrobial agents, Synergistic effect, Multi-drug resistant pathogens

\section{Background}

The crisis of antibiotic resistance has been acknowledged as a global health emergency by WHO [1]. Concomitant to increasing rates of antibiotic resistance, the discovery of novel antimicrobials has stalled. According to a recent report, most of the new antimicrobials currently in clinical trials are the derivatives of the existing antibiotics [2]. Thus, their modes of action are similar to the parent drug that offers a short term solution to the problem of antibiotic resistance. Hence, novel therapeutic options for

*Correspondence: drsukhrajkaur@gmail.com

Department of Microbiology, Guru Nanak Dev University, Amritsar,

Punjab, India treating MDR infections are urgently required. Bacteriocins are considered as the next wave of protein antibiotics owing to their unique modes of action such as disruption of cell membrane integrity, inhibition of protein production, DNA replication and septum formation [3]. The applications of bacteriocins are being explored in different areas, such as healthcare, food preservation, and veterinary medicines [4]. Bacteriocins such as nisin and pediocin purified from lactic acid bacteria (LAB) have evoked commercial interest. Nisin has shown therapeutic effects for the treatment of mastitis in both human [5] and animal studies [6]. Apart from their use as standalone therapeutics, bacteriocin-antibiotic combinations have tremendous value in terms of decreasing the

c) The Author(s) 2020. This article is licensed under a Creative Commons Attribution 4.0 International License, which permits use, sharing, adaptation, distribution and reproduction in any medium or format, as long as you give appropriate credit to the original author(s) and the source, provide a link to the Creative Commons licence, and indicate if changes were made. The images or other third party material in this article are included in the article's Creative Commons licence, unless indicated otherwise in a credit line to the material. If material is not included in the article's Creative Commons licence and your intended use is not permitted by statutory regulation or exceeds the permitted use, you will need to obtain permission directly from the copyright holder. To view a copy of this licence, visit http://creativeco mmons.org/licenses/by/4.0/. The Creative Commons Public Domain Dedication waiver (http://creativecommons.org/publicdomain/ zero/1.0/) applies to the data made available in this article, unless otherwise stated in a credit line to the data. 
minimum inhibitory concentration (MIC) of antibiotics. For example, thuricin CD reduced the MIC of various antibiotics against Clostridium spp. [7]; and nisin showed synergistic interaction with various antibiotics against methicillin-resistant Staphylococcus aureus and vancomycin resistant enterococci [8]. This strategy will, in turn, reduce the probability of development of antibiotic resistance among pathogens [9].

Salmonella-related enteric infection is a significant health problem worldwide that poses a substantial economic burden to both developed and under-developed countries [10]. Every year, 11-20 million people become sick, and 128,000 to 161,000 people die due to typhoid fever [11]. The antibiotics commonly used for the treatment of typhoid fever belong to the classes ß-lactam and fluoroquinolone. The fast-emerging resistance to quinolones among Salmonella spp. has necessitated the use of other antimicrobials such as ceftriaxone, a third generation cephalosporin and azithromycin [12]. Recently sporadic cases of ceftriaxone- or azithromycin-resistant S. typhi have also been reported. Therefore, Salmonella has been classified as a high priority pathogen for the development of novel antimicrobials [13, 14]. A bacteriocin-antibiotic combination is an innovative approach to lower the dose of currently used antibiotics thereby decreasing the selective pressure that leads to the emergence of resistant bacterial strains. Thus, in this study we have purified and characterized a low molecular weight enterocin, E20c from a probiotic strain of Enterococcus hirae 20c that was previously isolated from healthy human vaginal swab samples [15]. Further, we studied the mechanism of antimicrobial activity of E20c and the interaction of E20c with conventionally used antibiotics against $S$. enterica.

\section{Results}

Purification and characterization of E20c

E20c was purified from the cell free culture supernatant (CS) of E. hirae 20c by ammonium sulphate precipitation followed by cation-exchange chromatography. Cationexchange chromatography resulted in a 2 -fold increase in the specific activity of E20c (Table 1) with the final yield percentage of 1.62. The active fractions were concentrated by lyophilization and subjected to U-HPLC and SDS PAGE analysis to check the purity of the protein. A single peak was observed in the U-HPLC chromatogram (Fig. 1a). The resolution of the concentrated active fractions on SDS-PAGE yielded a single band with a molecular weight of approximately $6.5 \mathrm{kDa}$ (Fig. 1b; Lane 2). Simulataneously, a lane of agar gel was cut and subjected to agar gel overlay assay. A clear zone corresponding to $6.5 \mathrm{kDa}$ band was obtained against the indicator strain $S$. enterica (Fig. 1b). Further, to characterize the protein band, it was cut, trypsin-digested and subjected to matrix-assisted laser desorption-ionization time-of-flight (MALDI TOF/TOF) mass spectrometry (MS) for protein identification. Peptide mass fingerprinting (Pmf) analysis of the fragments obtained was performed by Matrix Science Mascot UK software, and significant $(\mathrm{p}<0.05)$ result was obtained. The analysis revealed eight peptides that shared similarity with $34 \%$ of the hypothetical protein of E. faecalis with significant $(\mathrm{p}<0.05)$ coverage score of 102 (Fig. 1c).

\section{Antimicrobial activity of purified enterocins}

Purified E20c had antimicrobial activities against various Gram-positive and Gram-negative pathogens viz. S. enterica, Shigella flexneri, Escherichia coli, Streptococcus pyogenes and Listeria monocytogenes. On the other hand, it did not inhibit any of the tested commensal lactobacilli spp. isolated from the stool samples of healthy children, and other tested pathogenic bacteria viz. Vibrio cholerae, Mycobacterium smegmatis, S. aureus, and Pseudomonas aeruginosa (Table 2 ).

\section{Physico-chemical characterization of purified E20c}

The thermostability of E20c was determined at different temperature treatments for different time periods. Results (Table 3) showed that the antimicrobial activity of E20c remained stable till $100{ }^{\circ} \mathrm{C}$ treatment for $60 \mathrm{~min}$. However, at the autoclaving temperature, its activity

Table 1 Purification of enterocin from E. hirae 20c

\begin{tabular}{|c|c|c|c|c|c|c|c|}
\hline Purification step & $\begin{array}{l}\text { Total } \\
\text { volume } \\
(\mathrm{ml})\end{array}$ & Activity (AU/ml) & Total activity $^{\mathrm{a}}(\mathrm{AU})$ & $\begin{array}{l}\text { Total } \\
\text { protein } \\
(\mathrm{mg})\end{array}$ & $\begin{array}{l}\text { Specific } \\
\text { activityb (AU/ } \\
\text { mg) }\end{array}$ & $\begin{array}{l}\text { Increase } \\
\text { in specific } \\
\text { activity }\end{array}$ & Yield (\%) \\
\hline CS & 1000 & 4266 & $4.2 \times 10^{6}$ & 250 & 16800 & 1 & 100 \\
\hline Ammonium sulphate ppt. & 50 & 17066 & $8.5 \times 10^{5}$ & 21 & 40476.2 & 2.41 & 20.24 \\
\hline Cation-exchange fraction & 1 & 68266 & $6.8 \times 10^{4}$ & 2 & 34000 & 2.02 & 1.62 \\
\hline
\end{tabular}

\footnotetext{
a Total activity $=$ activity $\times$ total volume of sample used at each purification step
}

b Specific activity $=$ total activity/total protein 


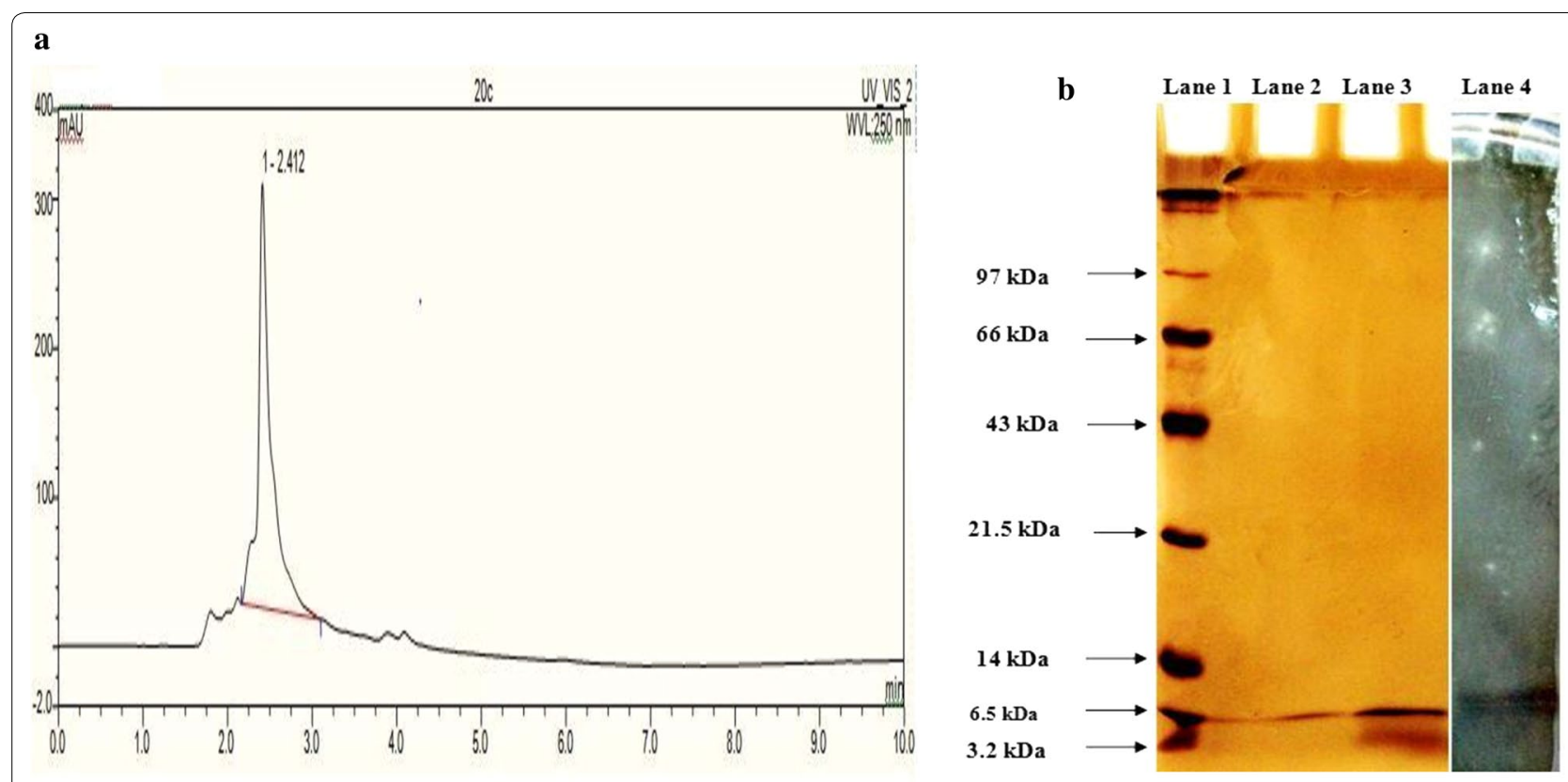

c

Protein sequence coverage: $34 \%$

Matched peptides shown in bold red.

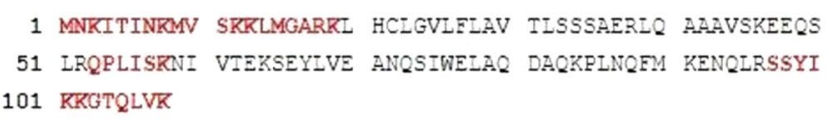

\begin{tabular}{|c|c|c|c|c|c|}
\hline Start - End & Observed & $\operatorname{Mr}(\exp t)$ & $\operatorname{Mr}(\operatorname{calc})$ & Delta $\mathrm{N}$ & Peptide \\
\hline $1-8$ & 977.6620 & 976.6547 & 976.5375 & 0.11721 & -.MNKITINK.M + Oxidation (M) \\
\hline $4-8$ & 588.1387 & 587.1314 & 587.3642 & -0.2328 & R.ITINR.M \\
\hline $9-13$ & 608.1362 & 607.1289 & 607.3363 & -0.20741 & R.MVSKR. L + Oxidation $(M)$ \\
\hline $14-19$ & 676.0795 & 675.0722 & 674.3897 & 0.68251 & R. LMGARK. L \\
\hline $14-19$ & 692.0516 & 691.0443 & 690.3847 & 0.65971 & R. LMGARR. L + Oxidation (M) \\
\hline $53-58$ & 685.4468 & 684.4395 & 684.4170 & 0.02250 & R.QPLISR.N \\
\hline $97-101$ & 597.3685 & 596.3612 & 596.3170 & 0.04430 & R.SSYIR.K \\
\hline $102-108$ & 773.5207 & 772.5134 & 772.4807 & 0.03271 & R.KGTQLVK. - \\
\hline
\end{tabular}

Fig. 1 Purification and characterization of E20c. a U-HPLC chromatogram of the purified E20c. b SDS-PAGE of purified E20c. Lane 1: molecular weight marker. Lane 2: cation-exchange fraction eluted with $0.4 \mathrm{mM} \mathrm{NaCl}$-containing sodium acetate buffer. Lane 3: cation-exchange fraction eluted with $0.2 \mathrm{mM} \mathrm{NaCl}$-containing sodium acetate buffer c PMF analysis of E20c. The PMF followed by MASCOT search showed the matched amino acid residues (in bold red) of the peptide fragments with the hypothetical protein of E. faecalis following NCBI BLASTsearch

was completely abrogated. Further, the purified E20c remained active at $\mathrm{pH}$ ranging from 2 to 8 ; maximum antimicrobial activity was observed at $\mathrm{pH} 4$ and 6.

The susceptibility of E20c to various enzymes was also determined. Results showed that treatment of E20c with proteinase $\mathrm{K}$, pepsin and trypsin resulted in complete abrogation of the antimicrobial activity. On the other hand, lipase treatment of E20c had no effect on the antimicrobial activity of E20c (Table 3).

\section{Hemolytic activity}

The toxicity of E20c was determined by testing its hemolytic activity against human red blood cells (RBCs). E20c at the highest concentration of $5 \mu \mathrm{g} / \mathrm{ml}$ did not cause any significant $(\mathrm{p}<0.001)$ hemolysis of RBCs as compared to the phosphate buffer saline (PBS)-treated negative contol. On the other hand, treatment of RBCs with $1 \%$ Triton $\mathrm{X}-100$ resulted in $98 \%$ hemolysis (Fig. 2). 
Table 2 Antimicrobial activity of E20C against various indicator bacterial strains

\begin{tabular}{ll}
\hline Indicator Bacteria & $\begin{array}{l}\text { Zone } \\
\text { of inhibition } \\
(\mathbf{m m})\end{array}$ \\
& E20c \\
\hline S. enterica Microbial Type Culture Collection (MTCC) 733 & $16 \pm 0.1$ \\
Es. coli MTCC 119 & $13 \pm 0.12$ \\
Sh. flexneri MTCC 1457 & $15 \pm 0.2$ \\
Lis. monocytogenes MTCC 657 & $14 \pm 0.03$ \\
V. cholerae MTCC 3906 & $-{ }^{a}$ \\
M. smegmatis MTCC 6 & - \\
St.pyogenes MTCC 1927 & $13 \pm 0.11$ \\
Staph. aureus MTCC 96 & - \\
P. aeruginosa MTCC 741 & - \\
L. plantarum L14 & - \\
L. fermentum L32 & - \\
L. pentosus S45 & - \\
L.fermentum L13 & - \\
L. plantarum L12 & - \\
L.fermentum L18 & - \\
L. casei S49 & -
\end{tabular}

Zones of inhibition $(\mathrm{mm})$ of E20c against various indicator strains were determined by using agar gel diffusion assay. The results are the mean \pm SD of three independent experiments

$-{ }^{\mathrm{a}}$ No zone of inhibition

\section{Minimum inhibitory concentration (MIC) and time-kill assay}

The MIC of E20c for S. enterica was determined by broth microdilution assay that showed that E20c inhibited the visible growth of $S$. enterica, and the MIC was calculated as $0.5 \mu \mathrm{g} / \mathrm{ml}$. Further, to determine the bactericidal mode of antimicrobial activity of E20c, time-kill assay of enterocin at $2 \times \mathrm{MIC}$ i.e. $1 \mu \mathrm{g} / \mathrm{ml}$ concentration was performed against $S$. enterica. Results showed that the treatment of S. enterica cells with E20c resulted in 2.7 and 5.0 $\log 10$ reduction in CFU/ml at 15 and $60 \mathrm{~min}$, respectively (Fig. 3).

\section{Effect of E20c on the cell membrane permeability}

The membrane damaging effect of E20c on S. enterica cells was determined by flow cytometry after staining with DNA intercalating dye, propidium iodide (PI) that stains only the cells having damaged membranes. Treatment of S. enterica cells with E20c resulted in increase in the PI fluorescence of cells from $17 \%$ at $0 \mathrm{~h}$ to $63 \%$ after $15 \mathrm{~min}$ and to $84 \%$ at $30 \mathrm{~min}$ (Fig. $4 \mathrm{a}$ ). The membrane damaging effect of E20c on S. enterica cells was simultaneously visualized by confocal microscopy.
Table 3 Physico-chemical characterization of E20c

\begin{tabular}{|c|c|c|}
\hline Physico-chemical parameter & Treatment & $\begin{array}{l}\text { Zone } \\
\text { of inhibition } \\
(\mathrm{mm})\end{array}$ \\
\hline & Untreated control & $16 \pm 0.11$ \\
\hline \multirow[t]{8}{*}{ Temperature } & $60^{\circ} \mathrm{C}(30 \mathrm{~min})$ & $16 \pm 0.12$ \\
\hline & $60^{\circ} \mathrm{C}(60 \mathrm{~min})$ & $14 \pm 0.10$ \\
\hline & $80^{\circ} \mathrm{C}(30 \mathrm{~min})$ & $14 \pm 0.22$ \\
\hline & $80^{\circ} \mathrm{C}(60 \mathrm{~min})$ & $14 \pm 0.08$ \\
\hline & $100^{\circ} \mathrm{C}(15 \mathrm{~min})$ & $14 \pm 0.14$ \\
\hline & $100^{\circ} \mathrm{C}(30 \mathrm{~min})$ & $13 \pm 0.15$ \\
\hline & $100^{\circ} \mathrm{C}(60 \mathrm{~min})$ & $13 \pm 0.15$ \\
\hline & $121^{\circ} \mathrm{C}(15 \mathrm{~min})$ & $-^{*}$ \\
\hline \multirow[t]{5}{*}{$\mathrm{pH}$} & 2 & $10 \pm 0.17$ \\
\hline & 4 & $16 \pm 0.11$ \\
\hline & 6 & $16 \pm 0.04$ \\
\hline & 8 & $13 \pm 0.24$ \\
\hline & 10 & - \\
\hline \multirow[t]{4}{*}{ Enzymes (1 mg/ml) } & Proteinase K & - \\
\hline & Pepsin & - \\
\hline & Trypsin & - \\
\hline & Lipase & $16 \pm 0.12$ \\
\hline
\end{tabular}

Zone of inhibition ( $\mathrm{mm}$ ) of E20c was determined by using agar gel diffusion assay against $S$. enterica. The results are the mean \pm SD of three independent experiments preformed in triplicates

- , No zone of inhibition observed

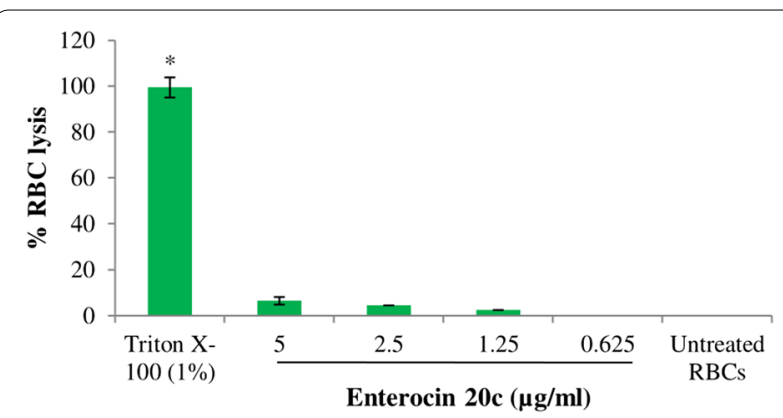

Fig. 2 Hemolytic activity of E20c. Enterocin at different concentrations was incubated with human RBCs in PBS for $1 \mathrm{~h}$. RBCs suspended in PBS were used as untreated control. Error bars represent $\pm S D$ of three independent experiments performed in triplicates. All groups were compared to the untreated control and asterisks show significant difference $(p<0.001)$ from untreated control

The images (Fig. 4b) of E20c-treated S. enterica cells stained with PI showed an exponential increase in the number of PI-fluorescent cells with increase in the treatment time as compared to the untreated cells. 


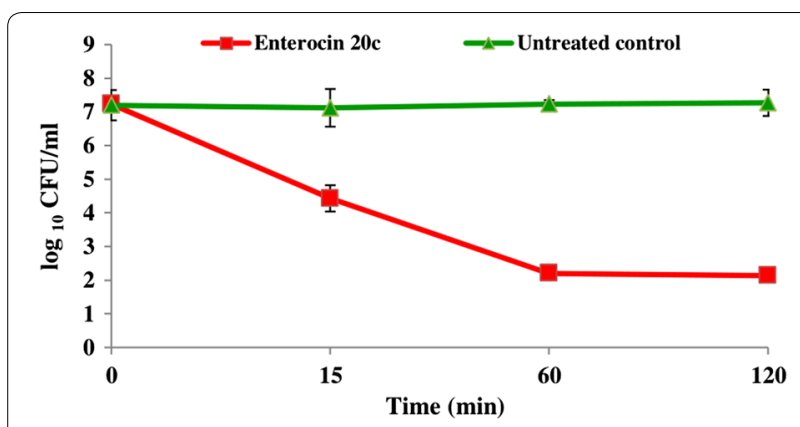

Fig. 3 Time-kill assay of E20c against S. enterica. The S. enterica cells were treated with $2 \times$ MIC of E20c i.e. $1 \mu \mathrm{g} / \mathrm{ml}$ and plated on nutrient agar plates at different time points. Error bars are representative of $\pm S D$ of the three independent experiments performed in triplicates

\section{Scanning electron microscopy (SEM) studies}

Further, the effect of E20c on the cell surface of S. enterica cells was visualized by electron microscopy. SEM images showed that the cell surface morphology of untreated $S$. enterica cells was smooth and continuous with good structural integrity (Fig. 5a). On the other hand, E20c treatment of S. enterica cells resulted in the shrinkage of their volume and appearance of surface indentations probably due to the loss of cell turgidity or cell membrane damage caused by the action of E20c.

\section{Efflux of potassium ions}

Disruption of the integrity of the cell membrane results in efflux of small ions. Therefore, we evaluated the effect of different doses of E20c on the efflux of potassium ions from S. enterica cells. As shown in Fig. 6, treatment of $S$. enterica cells with E20c resulted in significant $(\mathrm{p}<0.05)$ increase in extracellular concentration of potassium ions at all time points in a dose-dependent manner. Efflux of potassium ions was observed within 2 min of the addition of E20c that peaked to 16.3 and 8.4 parts per million (ppm) at concentrations 1.0 and $0.5 \mu \mathrm{g} / \mathrm{ml}$, respectively at 6 min, after which the effect plateaued (Fig. 6).

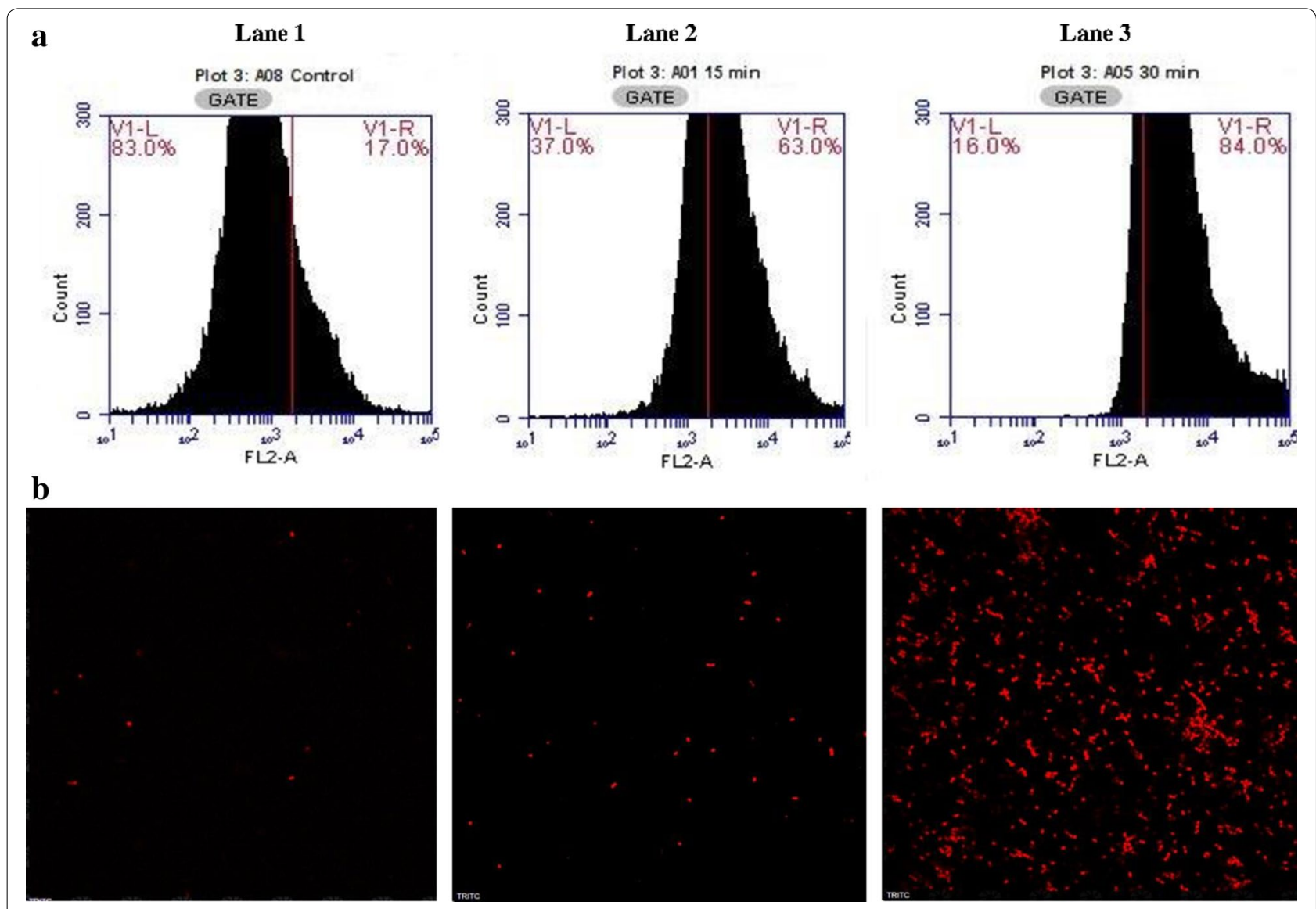

Fig. 4 a Histograms showing fluorescence of PI-stained enterocin-treated/untreated S. enterica cells b confocal microscopic images depicting PI fluorescence of enterocin-treated/untreated S. enterica cells. Lane $\mathbf{1}$ shows fluorescence of untreated S. enterica cells. Lane $\mathbf{2}$ and Lane $\mathbf{3}$ show fluorescence after 15 and 30 min of enterocin treatments, respectively. S. enterica cells in the mid-log phase were suspended in PBS and treated with $1 \mu \mathrm{g} / \mathrm{ml}$ of E20c for 15 and $30 \mathrm{~min}$. Thereafter, the cells were stained with PI and the fluorescence was determined in flow cytometer. Data is represented as histograms with counted bacterial events displayed on y axis and increase in fluorescence on $\mathrm{x}$ axis 

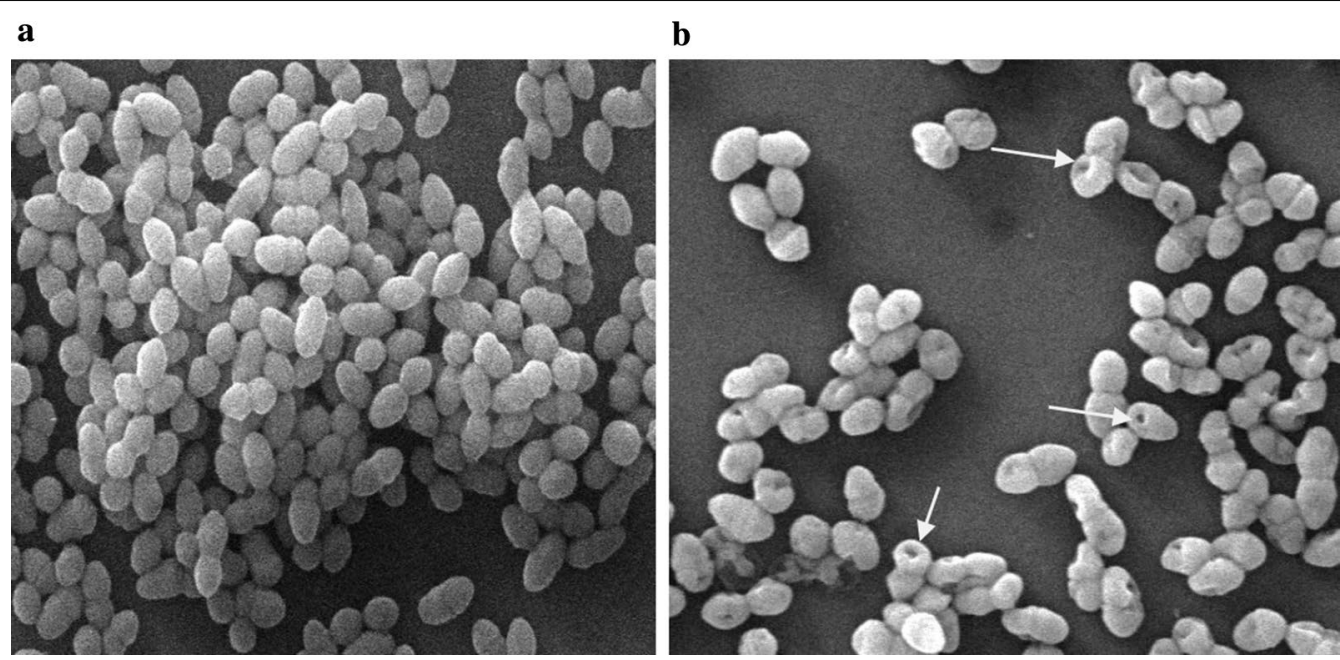

Fig. 5 Scanning electron microscopy images of E20c-treated/untreated S. enterica cells at $15000 \mathrm{X}$ magnification a untreated S. enterica cells, b S. enterica cells treated with $1 \mu \mathrm{g} / \mathrm{ml}$ of E20c for $60 \mathrm{~min}$

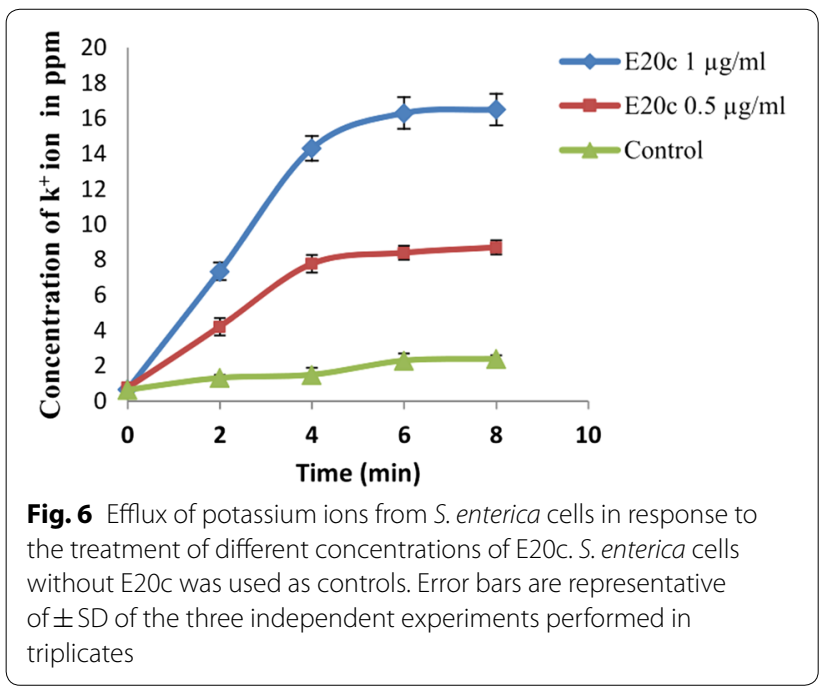

\section{Checkerboard titrations}

The antibiotic susceptibility profile of S. enterica MTCC 733 used in the study was determined by standard Kirby Bauer method that showed that it was resistant to number of antibiotics in different classes (Additional file 1, Table S1). Fast emerging antibiotic resistance among $S$. enterica strains is a serious problem that warrants novel alternatives. One of the alternatives could be to use bacteriocins as adjuncts to lower the therapeutic doses of antibiotics. Thus, interaction of E20c with conventional antibiotics and its effect on lowering the MIC of antibiotics for S. enterica was studied by using checkerboard titrations. Interestingly, as shown in Table 4, the MIC of E20c for S. enterica was lower than the MIC of all the tested antibiotics. Further, checkerboard titrations revealed that E20c had synergistic interaction with

Table 4 MIC and FICl of E20c alone and in combination with antibiotics against S. enterica

\begin{tabular}{|c|c|c|c|c|c|c|c|}
\hline \multirow[t]{2}{*}{ Antibiotic } & \multicolumn{3}{|c|}{$\mathrm{MIC}(\mu \mathrm{g} / \mathrm{ml})$} & \multirow[t]{2}{*}{ FIC of antibiotic } & \multirow{2}{*}{$\begin{array}{l}\text { FIC } \\
\text { of enterocin } \\
20 c\end{array}$} & \multirow{2}{*}{$\begin{array}{l}\mathrm{FICl} \\
\text { antibiotic + E20C }\end{array}$} & \multirow{2}{*}{$\begin{array}{l}\text { Fold decrease } \\
\text { in MIC } \\
\text { of antibiotic }\end{array}$} \\
\hline & Antibiotic & E20c & Antibiotic/E20c & & & & \\
\hline Ampicillin & 12.5 & 0.5 & $1.81 / 0.07$ & 0.14 & 0.14 & 0.28 & 6.9 \\
\hline Penicillin & 25 & 0.5 & $1.9 / 0.156$ & 0.08 & 0.32 & 0.39 & 13.1 \\
\hline Ceftriaxone & 43.5 & 0.5 & $6.7 / 0.07$ & 0.15 & 0.14 & 0.29 & 6.4 \\
\hline Ciprofloxacin & 400 & 0.5 & $31.2 / 0.15$ & 0.078 & 0.31 & 0.38 & 12.8 \\
\hline Carbenicillin & 21.7 & 0.5 & $6.5 / 0.15$ & 0.29 & 0.31 & 0.60 & 3.3 \\
\hline
\end{tabular}

$\mathrm{FICl}=\mathrm{FIC}$ of antibiotic $+\mathrm{FIC}$ of E20C $=$ (MIC of antibiotic in combination/MIC of antibiotic alone $)+(\mathrm{MIC}$ of E20c in combination/MIC of E20c alone). The interaction was interpreted as follows: synergy, $\mathrm{FICl} \leq 0.5$; indifference, $0.5<\mathrm{FICl}<2$; and antagonism, $\mathrm{FICl}>2$. The values are mean $\pm \mathrm{SD}$ of experiments performed in triplicate 
ciprofloxacin and the tested ß-lactams viz. ampicillin, penicillin and ceftriaxone as the fractional inhibitory concentration index (FICI) obtained in combination with E20c in all the cases was less than 0.5. E20c lowered the MIC of ciprofloxacin by 12.8 times and that of the three tested ß-lactams in the range 6.4-13.1 (Table 4). However, in combination with carbenicillin, E20c showed indifference.

\section{Discussion}

In this study, enterocin E20c was purified from the CS of probiotic strain E. hirae 20c. E. hirae 20c was selected for the purification of E20c as its CS inhibited the growth of several Gram-negative bacterial pathogens, and the strain possessed good probiotic properties with no known virulence factors or genes [15]. The purified E20c was obtained as a single peak with the molecular weight of $6.5 \mathrm{kDa}$. The peak was further characterized by MALDI TOF/TOF MS and Pmf analysis. MASCOT search of the peptides obtained by trypsin digestion did not matched with any of the known bacteriocin; but it shared 34\% homology with a hypothetical protein of $E$. faecalis. The sequence of the hypothetical protein was searched by Phobius software [16] to determine the presence of signal peptide that indicates the secretory nature of the protein. Results showed that the hypothetical protein possessed 41 amino acid long signal sequence (data not shown) that indicated its secretory nature. One of the peptide fragment of E20c matched with the signal peptide sequence of the hypothetical protein thereby indicating the secretory nature of E20c. The physico-chemical characterization of E20c was done that showed that it was both heat stable and stable at $\mathrm{pH}$ ranging between 2 and 8 . The antimicrobial spectrum of E20c showed that it was active against both Gram-positive and Gram-negative pathogens but not against commensal lactobacilli isolated from the stool samples of healthy individuals. The antibiotic susceptibility profiles (Additional file 1 ) of $S$. enterica, Sh. flexneri and Es. coli strains used in the current study revealed that all the three pathogens could be MDR strains as they were resistant to at least one agent in more than 3 different antibiotic classes. Thus, enterocin 20c inhibited the growth of MDR Gram-negative human gut pathogens but not that of commensal gut lactobacilli spp.

Further, literature search revealed that only two enterocins, i.e., hiracin JM79 and LD3 have been earlier reported from $E$. hirae. Hiracin JM79 of molecular weight $8.157 \mathrm{kDa}$ had antimicrobial activities against Gram-positive bacteria only, including various species of Lactobacillus, Enterococcus, and Pediococcus [17]. Whereas, enterocin LD3 (6 kDa) inhibited Gram-positive bacteria such as Enterococcus, Lactococcus spp. including lactobacilli, and Gram-negative bacteria, including $S$. typhi [18]. E20c, in contrast, had no activity against human commensal lactobacilli. Commensal gut lactobacilli are beneficial to human health owing to the number of important functional properties; therefore, their inhibition may lead to gut dysbiosis [19].

Further, time-kill studies were performed to determine the mode of action of E20c against S. enterica. Antimicrobial agents are categorized as bactericidal if they result in $>3 \log$ decrease in CFU/ml [20]. Treatment of $S$. enterica cells with E20c at a dose of $1 \mu \mathrm{g} / \mathrm{ml}$, resulted in a time-dependent decrease in the viable cell counts with 5 $\log 10$ CFU change within $60 \mathrm{~min}$. This indicated the bactericidal mode of action of the enterocin. Similar results were obtained for bacteriocin BM1157 which caused more than $3 \log 10$ decrease in CFU of Lis. monocytogenes after 30 min treatment [21]. In another study, pentocin JL-1 treatment resulted in $4.5 \log 10$ decrease in CFUs of Staph. aureus cells within $60 \mathrm{~min}$ [22]. As bacteriocins are known to kill the target cell by permeabilizing their cell membrane due to their cationic nature, the effect of E20c on the cell membrane permeability of S. enterica cells was determined by flow cytometry and confocal microscopy. E20c treatment of S. enterica cells resulted in membrane destabilization that led to enhanced uptake of PI within the cells as shown by increase in their fluroscence with time. These results are similar to that reported for other bacteriocins such as nisin [23] and lactacin F [24]. Further, the SEM images of E20c-treated $S$. enterica clearly showed cell surface damaging effects such as cell shrinkage and surface indentations due to the loss of cell turgidity or membrane damage. Disruption of cell membrane integrity is associated with efflux of small molecules such as potassium ions and ATP, and large molecules such as proteins depending on the size of the pore [25]. Our results showed that E20c disrupted the cell membrane integrity of $S$. enterica cells resulting in efflux of potassium ions in a dose-dependent manner. Other enterocins such as enterocin P [26] and enterocin CRL35 [27] are also known to induce the efflux of potassium ions from the target bacterial cell.

Conventional antibiotics such as ampicillin and ciprofloxacin are commonly used for the treatment of $S$. enterica infections. However, resistance to these antibiotics limits the therapeutic options. The antibiotic susceptibility profile of $S$. enterica used in this study indicated that the strain was resistant to a number of antibiotics in the classes $\beta$-lactam, fluoroquinolone, tetracycline and aminoglycoside (Additional file 1; [28]). MIC of penicillin for S. enterica strain used in the current study was $25 \mu \mathrm{g} /$ $\mathrm{ml}$ and that of ciprofloxacin was $400 \mu \mathrm{g} / \mathrm{ml}$. Next, we determined the ability of E20c to lower the MIC of resistant antibiotics. Checkerboard titrations was revealed 
synergistic interaction between E20c and conventional antibiotics such as ampicillin, penicillin, ceftriaxone and ciprofloxacin. Treatment of $S$. enterica cells with conventional antibiotics in the presence of E20c lowered the MIC of antibiotics in the range 6.4 (ceftriaxone) to 13.1 (penicillin). However, no synergism was observed with carbenicillin. Few other studies have reported the synergistic effect of purified bacteriocins with antibiotics. For example, Singh et al. [29] showed the synergistic effect of nisin in combination with ampicillin, ceftriaxone, and cefotaxime against the clinical strains of S. enterica serovar Typhi. Enterocin CRL35 at a very low dose of $4 \mathrm{ng} /$ $\mathrm{ml}$ showed synergy with tetracycline, erythromycin, and chloramphenicol but not with ciprofloxacin and ampicillin against Lis. innocua [30]. In another study, enterocins DD28 and DD93 at the dose of $50 \mu \mathrm{g} / \mathrm{ml}$ synergized with erythromycin and kanamycin against methicillin-resistant Staph. aureus [31].

The S. enterica strain used in the present study showed resistance to antibiotics penicillin, methicillin and ciprofloxacin. ß-lactam antibiotics are known to enter Gram-negative bacterial cells through porins; whereas, fluoroquinolones enter through both porins and lipid-mediated pathways [32]. Therefore, one of the mechanism of ß-lactam and ciprofloxacin resistance used by Gram-negative bacteria includes loss or severe reduction in the numbers of porins, or mutation leading to reduced permeability of porins [33]. Thus, the mechanism by which E20c synergized with these antibiotics may be explained by their ability to enhance the permeability of the outer membrane to the antibiotics thereby reversing their resistance and reducing their MIC. Another study that evaluated the combinations of nisin-cefotaxime and nisin-ceftriaxone against $S$. enterica showed that the combination of bacteriocin- $\beta$-lactams significantly increased $(\mathrm{p}<0.05)$ the cell membrane permeability of the treated cells to hydrophobic fluorescent probe, 1-N-phenylnaphthylamine [29]. Further, they also observed dose- and time-dependent inhibition of DNA, RNA and protein synthesis in the presence of the tested combinations.

\section{Conclusion}

E20c appears to be a novel low molecular weight enterocin having bactericidal activity against several Gram-negative bacteria due to its cell membrane-permeabilising action. It is a promising candidate for standalone and adjunct therapy against $S$. enterica infections. With fast emerging problem of multidrug resistance in Salmonella-related infections, enterocin E20c can serve as an effective therapeutic option that should be further evaluated in animal models.

\section{Methods}

\section{Bacterial strains}

$E$. hirae 20c used for the purification of enterocin was obtained from the vaginal microflora of healthy women as reported previously [15]. Commensal Lactobacillus spp. used as indicator strains were isolated from the stool samples of healthy children and the method for the isolation and characterization were reported in the previous study [34]. All the LAB strains were cultured in De-Man Rogosa and Sharpe (MRS) media at $37{ }^{\circ} \mathrm{C}$ in anaerobic jars. All the chemicals and bacterial growth media used in this study, except where mentioned, were purchased from HiMedia Laboratories Pvt. Ltd. (Mumbai, India).

All the indicator pathogenic strains used in the study were procured from MTCC, Institute of Microbial Technology, Chandigarh, India. The pathogenic indicator strains, except M. smegmatis were propagated in Brain heart infusion (BHI) broth at $37^{\circ} \mathrm{C}$ under aerobic stationary conditions. M. smegmatis was cultured in the $7 \mathrm{H} 9$ broth supplemented with Middlebrook OADC Growth Supplement containing bovine serum albumin fraction $\mathrm{V}$ and Tween 80 under aerobic conditions at $37^{\circ} \mathrm{C}$.

\section{Agar gel diffusion assay}

The antimicrobial activities of E20c against various indicator pathogenic bacterial strains was determined by modified agar gel diffusion assay [35].

\section{Purification and characterization of E20c}

E20c was purified from the CS of E. hirae 20c by using ammonium sulphate precipitation followed by cationexchange chromatography. Briefly, 1 litre of MRS broth was inoculated with $2 \%$ of overnight grown culture of $E$. hirae 20c and incubated at $37^{\circ} \mathrm{C}$ for $16 \mathrm{~h}$ in anaerobic jars. To prepare the CS, culture was centrifuged at 10,000 rpm at $4{ }^{\circ} \mathrm{C}$. The proteins in the CS were precipitated by adding ammonium sulphate till $60 \%$ saturation $(\mathrm{w} / \mathrm{v})$ at $4{ }^{\circ} \mathrm{C}$. The protein precipitates were separated by centrifugation $\left(10,000 \mathrm{rpm}\right.$ at $\left.4{ }^{\circ} \mathrm{C}\right)$ and dissolved in sodium acetate buffer (20 mM; pH 4.5). The dissolved precipitates were further desalted by passing through Biogel PD-10 column (GE HealthCare, USA) equilibrated with sodium acetate buffer. The active fractions obtained from Biogel PD-10 column were pooled and applied on SP-Sepharose Fast Flow cation-exchange column $(50 \times 10 \mathrm{~mm}$; GE Healthcare) and eluted with a linear salt gradient of 0.1 to $1 \mathrm{M}$ $\mathrm{NaCl}$ in sodium acetate buffer. The fractions were tested for the antimicrobial activity against various indicator pathogens by agar gel diffusion assay. The active fractions were lyophilized and dissolved in MilliQ water. At every purification step, protein concentration was determined by using Bradford's method [36]. 
Denaturing gel electrophoresis was carried out under reducing conditions to determine the molecular weight of the purified E20c [37]. Protein separation was carried out in $15 \%(\mathrm{w} / \mathrm{v})$ polyacrylamide separating gel and $6 \%$ stacking gel. After electrophoresis, one lane of the gel was cut and stained with silver nitrate (SRL, India) whereas, the other lane of the gel was subjected to agar gel overlay assay against S. enterica in BHI soft agar [38].

\section{MALDI TOF/TOF MS}

The silver-stained gel bands were cut, destained, trypsinized, extracted and subjected to MS by using MALDITOF/TOF-Proteomics Analyzer (UltrafleXtremeTM mass spectrometer; Bruker Daltonics Inc. Germany). A combined MS and LIFT-MS/MS were performed using BioTools 3.0 software (Bruker Daltonics Inc. Germany). The TOF spectra were recorded in positive ion reflector mode with a mass range from 700 to 3500 Da. Five hundred shots were accumulated for each spectra. Two most abundant peptide ions were then subjected to fragmentation analysis to determine the peptide sequence. Database search was performed using MASCOT search engine (Version 2.1) and NCBInr protein databases. The parameters used for search were as follows: taxonomy, Firmicutes; enzyme, trypsin; the fixed modification, carbamidomethyl $(\mathrm{C})$; the variable modification, Glu-> pyro-Glu (N-term Q) and oxidation (M); parent ion mass tolerance at $50 \mathrm{ppm}$ and MS/MS mass tolerance of $0.7 \mathrm{Da}$; one missed cleavage allowed. The identified proteins among the top hits on the search report with individual ions scores $>44$ indicated identity or extensive homology $(\mathrm{p}<0.05)$.

\section{Physico-chemical characterization of purified E20c}

Thermostability of purified E20c, was determined by subjecting it at a concentration of $1 \mu \mathrm{g} / \mathrm{ml}$ to different temperatures for different time periods. For determining the $\mathrm{pH}$ sensitivity, the $\mathrm{pH}$ of E20c was set to different values between 2 and 10 and incubated at $37{ }^{\circ} \mathrm{C}$ for $1 \mathrm{~h}$. The $\mathrm{pH}$ was reset at 6.5 and the antimicrobial activity was determined by agar well diffusion assay. Further, the effect of various proteolytic and lipolytic enzymes on E20c was determined. E20c was treated with enzymes proteinase $\mathrm{K}$, trypsin, pepsin, and lipase (Sigma Aldrich, India) at the concentration of $1 \mathrm{mg} / \mathrm{ml}$ for $1 \mathrm{~h}$ at $37{ }^{\circ} \mathrm{C}$, followed by heat inactivation at $60{ }^{\circ} \mathrm{C}$ for $10 \mathrm{~min}$. The residual antimicrobial activity was determined by agar gel diffusion assay.

\section{Safety evaluation}

Hemolytic activity of E20c was evaluated by hemoglobin release assay [39] against human RBCs. The defibrinated human blood was centrifuged at $1200 \mathrm{rpm}$ for $15 \mathrm{~min}$ at
$37{ }^{\circ} \mathrm{C}$ and $\mathrm{RBC}$-containing pellet was suspended in $10 \mathrm{ml}$ PBS (pH 7.2). RBC suspensions $(500 \mu \mathrm{l})$ were incubated with $100 \mu \mathrm{l}$ of different concentrations of E20c at $37{ }^{\circ} \mathrm{C}$ for $1 \mathrm{~h}$. Thereafter, the suspensions were centrifuged at $3000 \mathrm{rpm}$ for $5 \mathrm{~min}$ and the hemoglobin release in the supernatant was monitored by taking $\mathrm{OD}_{415}$. TritonX-100 (1\%) treated and PBS-treated RBCs were used as positive and negative control, respectively. The percentage of RBC lysis was calculated by using the equation: $\left(A_{T}-A_{C}\right) /\left(A_{X}-A_{C}\right) \times 100$.

Where $A_{T}$ is $O_{415}$ of E20c-treated RBCs, $A_{C}$ is $O_{415}$ of PBS treated-RBCs and $\mathrm{A}_{\mathrm{X}}$ is $\mathrm{OD}_{415}$ of $1 \%$ tritonX100-treated RBCs.

\section{Determination of MIC and time-kill studies}

MIC of E20c and conventional antibiotics against $S$. enterica was determined by broth dilution method [40]. Time-kill assay was performed as per the protocol by Joshi et al. [41] with slight modifications. E20c at the concentration of $2 \times \mathrm{MIC}$ was added to $1 \mathrm{ml}$ of $\mathrm{BHI}$ and inoculated with $10^{7} \mathrm{CFU} / \mathrm{ml}$ of $S$. enterica cells. The cells were incubated at $37{ }^{\circ} \mathrm{C}$ and $100 \mu \mathrm{l}$ of the culture at different time points were serially-diluted and plated on nutrient agar plates for viable cell counting.

\section{Effect of E20c on the cell membrane permeability}

The effect of E20c on cell membrane integrity was studied by using a flow cytometric method [42] and confocal microscopy with slight modifications. S. enterica cells were suspended in PBS at a concentration of $1 \times 10^{6} \mathrm{CFU} / \mathrm{ml}$. E20c $(1 \mu \mathrm{g} / \mathrm{ml})$ was added to the cell suspension and incubated at $37{ }^{\circ} \mathrm{C}$ for 15 and $30 \mathrm{~min}$. The cell suspension was centrifuged $(10,000 \mathrm{rpm} ; 5 \mathrm{~min})$ to obtain cell pellet that was treated with PI $(1 \mu \mathrm{g} / \mathrm{ml})$ and incubated for $15 \mathrm{~min}$ at $4{ }^{\circ} \mathrm{C}$ under dark. Fluorescence of $S$. enterica cells was monitored by running the cells through flow cytometer (Accuri C6 Flow Cytometer) in FL2 channel. Data was analyzed by using C Flow Plus software (Becton-Dickinson, San Jose, CA, USA). Simultaneously, $10 \mu \mathrm{l}$ of PI-stained cell suspension was placed on the glass slides, fixed with $5 \mu$ flourmount solution (Sigma) and viewed under a confocal microscope (Nikon, A1R).

\section{Scanning electron microscopy studies}

SEM was performed to view the morphological changes induced in the E20c-treated S. enterica cells. Overnight grown culture of $S$. enterica at $\mathrm{OD}_{595}$ of 0.3 was treated with E20c $(1 \mu \mathrm{g} / \mathrm{ml})$ for $60 \mathrm{~min}$ at ambient temperature. After $60 \mathrm{~min}$, the cells were centrifuged at 10,000 rpm for $5 \mathrm{~min}$ and re-suspended in PBS. Untreated S. enterica cells were used as control. The cell suspensions were placed on the glass coverslips and dehydrated according 
to the method by Kalab et al. [43]. Silver sputtering was done and the stubs were examined under SEM-EVO LS-10 (Carl Zeiss, Germany).

\section{Efflux of potassium ions}

Destabilization of the cell membrane results in efflux of small ions. Therefore, we evaluated the effect of different doses of E20c treatment of S. enterica on the extracellular potassium ion concentration [44]. The bacterial cells grown till mid-log phase were centrifuged $(10,000 \mathrm{rpm}$; $5 \mathrm{~min}$ ) to obtain cell pellet, washed twice and suspended in $2.5 \mathrm{mM}$ sodium HEPES (4-(2-hydroxyethyl)-1-piperazineethanesulfonic acid) buffer ( $\mathrm{pH} 7.0)$ to obtain an $\mathrm{OD}_{595}$ of 1.0. Purified E20c was added to the cell pellets of $S$. enterica in two separate tubes to obtain final concentrations of $1 \mu \mathrm{g} / \mathrm{ml}$ and $0.5 \mu \mathrm{g} / \mathrm{ml}$. Samples $(1 \mathrm{ml})$ were taken at intervals of $2,4,6$, and 8 min and immediately chilled on ice. S. enterica cells without E20c was used as controls. The samples were filter sterlised $(0.2 \mu)$ to separate the cells and the potassium ion concentration in the supernatants was determined by flame photometry (Systronics 128, Gujarat, India). The experiment was performed thrice in triplicates.

\section{Checkerboard titrations}

Interaction of E20c with conventional antibiotics was determined by using checkerboard titration method [45]. Each antimicrobial was used at tenfold higher concentration than its MIC and diluted to test concentrations higher, equal and lower than MIC. Two-fold serial dilutions of the combination of antibiotics with E20c were made in $100 \mu \mathrm{l}$ Mueller-Hinton broth in 96-well microtitre plate. Overnight grown culture of $S$. enterica was diluted using sterile $\mathrm{BHI}$ broth to obtain $\mathrm{OD}_{595}$ of 0.1 $\left(10^{8} \log 10 \mathrm{CFU} / \mathrm{ml}\right)$. Five microlitres $\left(5 \times 10^{5} \log 10 \mathrm{CFU}\right)$ of the culture suspension was added to each well and the plate was incubated at $37{ }^{\circ} \mathrm{C}$ for $24 \mathrm{~h}$ and observed for visual turbidity. The FICI was calculated as follows: $\mathrm{FICI}=\mathrm{FIC}$ of antibiotic + FIC of E20c, where FIC of antibiotic is the MIC of antibiotic in the combination/MIC of antibiotic alone, and FIC of E20c is the MIC of E20c in the combination/MIC of E20 alone. FICI $\leq 0.5$ indicate synergy; $0.5<\Sigma F I C<2$ indicate Indifference; and $\Sigma$ FIC $>2$ indicate antagonism.

\section{Supplementary information}

Supplementary information accompanies this paper at https://doi. org/10.1186/s12934-020-01352-x.

Additional file 1: Table S1: Antibiotic susceptibility profile of Salmonella enterica MTCC 733. Table S2: Antibiotic susceptibility profile of E. coli MTCC1 19. Table S3: Antibiotic susceptibility profile of Shigella flexneri MTCC 1457.

\section{Abbreviations}

CS: Culture supernatant; LAB: Lactic acid bacteria; MRS: De-Man Rogosa and Sharpe; MIC: Minimum inhibitory concentration; FIC: Fractional inhibitory concentration; RBC: Red blood cells; WHO: World health organization; $\mathrm{BHI}$ : Brain heart infusion media; CFU: Colony forming units; PBS: Phosphate buffered saline; MS: Mass spectrometry; PMF: Peptide mass fingerprinting; HEPES: 4-(2-hydroxyethyl)-1-piperazineethanesulfonic acid.

\section{Authors' contributions}

SK conceived the idea and supervised the experiments. PS and SK designed the experiments and PS performed all of the experiments except potassium efflux studies. MR designed and executed potassium efflux studies and flame photometry. PS and SK discussed the results and contributed to the final manuscript. All authors read and approved the final manuscript.

\section{Funding}

This work was supported by research grants (Grant Number: 42-478/2013 SR) sponsored by University Grants Commission (UGC), New Delhi, India and Promotion of University Research and Scientific Excellence (PURSE) by Department of Science and Technology, India. Preeti Sharma is thankful to University of Potential for Excellence scheme of UGC for the fellowship. Muzamil Rashid is thankful to Rashtriya Uchchattar Shiksha Abhiyan (RUSA), Component 2.0 scheme of Ministry of Human Resource Development, Government of India for Junior Research Fellowship.

\section{Availability of data and materials}

All data generated or analysed during this study are included in this published article.

\section{Ethics approval and consent to participate}

For the isolation of RBCs, the blood of healthy volunteers above the age of $18 \mathrm{yrs}$ was drawn after taking their written informed consent. The protocol was approved by the Institutional Human Ethics Committee, Guru Nanak Dev University and performed in accordance with the guidelines of the Ethics Committee.

\section{Consent for publication}

Not applicable.

\section{Competing interests}

The authors declare that they have no competing interests.

Received: 19 January 2020 Accepted: 15 April 2020

Published online: 04 May 2020

\section{References}

1. Toner E, Adalja A, Gronvall GK, Cicero A, Inglesby TV. Antimicrobial resistance is a global health emergency. Health Secur. 2015;13(3):153-5.

2. Pewtrusts. https://www.pewtrusts.org//media/assets/2018/09/antibiotic s_currently_in_global_clinical_development_sept2018.pdf.

3. Cavera VL, ArthurTD, Kashtanov D, Chikindas ML. Bacteriocins and their position in the next wave of conventional antibiotics. Int J Antimicrob Agents. 2015;46(5):494-501.

4. Chikindas ML, Weeks R, Drider D, Chistyakov VA, Dicks LM. Functions and emerging applications of bacteriocins. Curr Opin Biotechnol. 2018;49:23-8.

5. Fernández L, Delgado S, Herrero H, Maldonado A, Rodríguez JM. The bacteriocin nisin, an effective agent for the treatment of Staphylococcal mastitis during lactation. J Hum Lact. 2008;24:311-6.

6. Wu J, Hu S, Cao L. Therapeutic effect of nisin Z on subclinical mastitis in lactating cows. Antimicrob Agents Chemother. 2007;51(9):3131-5.

7. Mathur H, O'Connor PM, Hill C, Cotter PD, Ross RP. Analysis of antiClostridium difficile activity of thuricin $C D$, vancomycin, metronidazole, ramoplanin, and actagardine, both singly and in paired combinations. Antimicrob Agents Chemother. 2013;57(6):2882-6.

8. Brumfitt W, Salton MR, Hamilton-Miller JM. Nisin, alone and combined with peptidoglycan-modulating antibiotics: activity against methicillinresistant Staphylococcus aureus and vancomycin-resistant enterococci. J Antimicrob Chemother. 2002;50:731-4. 
9. Mathur H, Field D, Rea MC, Cotter PD, Hill C, Ross RP. Bacteriocinantimicrobial synergy: a medical and food perspective. Front Microbiol. 2017:8:1205. https://doi.org/10.3389/fmicb.2017.01205.

10. Crump JA, Luby SP, Mintz ED. The global burden of typhoid fever. Bull World Health Organ. 2004;82:346-53.

11. WHO. (2018). http://www.who.int/mediacentre/factsheets/typhoid/en/.

12. Crump JA, Sjölund-Karlsson M, Gordon MA, Parry CM. Epidemiology, clinical presentation, laboratory diagnosis, antimicrobial resistance, and antimicrobial management of invasive Salmonella infections. Clin Microbiol Rev. 2015;28(4):901-37.

13. Karkey $A$, Thwaites $G E$, Baker $S$. The evolution of antimicrobial resistance in Salmonella Typhi. Curr Opin Gastroenterol. 2018;34(1):25-30.

14. WHO. Global priority list of antibiotic-resistance bacteria to guide research, discovery, and development of new antibiotics. Geneva: WHO; 2017.

15. Sharma P, Kaur S, Kaur R, Kaur M, Kaur S. Proteinaceous secretory metabolites of probiotic human commensal Enterococcus hirae 20c, E. faecium $12 \mathrm{a}$ and $\mathrm{L} 12 \mathrm{~b}$ as antiproliferative agents against cancer cell lines. Front Microbiol. 2018. https://doi.org/10.3389/fmicb.2018.00948.

16. Käll L, Krogh A, Sonnhammer EL. A combined transmembrane topology and signal peptide prediction method. J Mol Biol. 2004;338(5):1027-36.

17. Sanchez J, Diep DB, Herranz C, Nes IF, Cintas LM, Hernández PE. Amino acid and nucleotide sequence, adjacent genes, and heterologous expression of hiracin JM79, a sec-dependent bacteriocin produced by Enterococcus hirae DCH5, isolated from Mallard ducks (Anas platyrhynchos). FEMS Microbiol Lett. 2007;270(2):227-36.

18. Gupta A, Tiwari SK, Netrebov V, Chikindas ML. Biochemical properties and mechanism of action of enterocin LD3 purified from Enterococcus hirae LD3. Probiotics Antimicrob Proteins. 2016;8:161-9.

19. Francino MP. Antibiotics and the human gut microbiome: dysbioses and accumulation of resistances. Front Microbiol. 2016;6:1543. https://doi. org/10.3389/fmicb.2015.01543.

20. Kalia V, Miglani R, Purnapatre KP, Mathur T, Singhal S, Khan S, Voleti SR, Upadhyay DJ, Saini KS, Rattan A, Raj VS. Mode of action of ranbezolid against staphylococci and structural modeling studies of its interaction with ribosomes. Antimicrob Agents Chemother. 2009;53:1427-33.

21. Yi L, Luo L, LüX. Heterologous expression of two novel bacteriocins produced by Lactobacillus crustorum MN047 and application of BM1157 in control of Listeria monocytogenes. Food Control. 2018;86:374-82.

22. Jiang $\mathrm{H}$, Zou J, Cheng H, Fang J, Huang G. Purification, characterization, and mode of action of Pentocin $\mathrm{JL}-1$, a novel bacteriocin isolated from Lactobacillus pentosus, against drug-resistant Staphylococcus aureus. Biomed Res Int. 2017;2017:1. https://doi.org/10.1155/2017/7657190.

23. Weeks ME, von Caron GN, James DC, Smales CM, Robinson GK. Monitoring changes in nisin susceptibility of Listeria monocytogenes Scott A as an indicator of growth phase using FACS. J Microbiol Meth. 2006;66(1):43-55.

24. Dal Peraro M, Van Der Goot FG. Pore-forming toxins: ancient, but never really out of fashion. Nat Rev Microbiol. 2016;14(2):77-92.

25. Herranz C, Cintas LM, Hernández PE, Moll GN, Driessen AJ. Enterocin P causes potassium ion efflux from Enterococcus faecium T136 cells. Antimicrob Agents Chemother. 2001;45(3):901-4.

26. Minahk CJ, Farías ME, Sesma F, Morero RD. Effect of enterocin CRL35 on Listeria monocytogenes cell membrane. FEMS Microbiol Lett. 2000;192(1):79-83.

27. Dalmau M, Maier E, Mulet N, Vinas M, Benz R. Bacterial membrane injuries induced by lactacin F and nisin. Int Microbiol. 2002;5:73-80.

28. Magiorakos AP, Srinivasan A, Carey RB, Carmeli Y, Falagas ME, Giske CG, et al. Multidrug-resistant, extensively drug-resistant and pandrug-resistant bacteria: an international expert proposal for interim standard definitions for acquired resistance. Clin Microbiol Infect. 2012;18(3):268-81.
29. Singh AP, Preet S, Rishi P. Nisin/ $\beta$-lactam adjunct therapy against Salmonella enterica serovar Typhimurium: a mechanistic approach. J Antimicrob Chemother. 2014;69(7):1877-87.

30. Minahk CJ, Dupuy F, Morero RD. Enhancement of antibiotic activity by sub-lethal concentrations of enterocin CRL35. J Antimicrob Chemother. 2004;53(2):240-6.

31. Al Atya AK, Belguesmia Y, Chataigne G, Ravallec R, Vachée A, Szunerits $S$, et al. Anti-MRSA activities of enterocins DD28 and DD93 and evidences on their role in the inhibition of biofilm formation. Front Microbiol. 2016;7:817. https://doi.org/10.3389/fmicb.2016.00817.

32. Nikaido H, Rosenberg EY, Foulds J. Porin channels in Escherichia colli: studies with beta-lactams in intact cells. J Bacteriol. 1983;153(1):232-40.

33. Delcour AH. Outer membrane permeability and antibiotic resistance. Biochim Biophys Acta Proteins Proteom. 2009;1794:808-16.

34. Kaur S, Kaur S, Sharma P, Singh J, Kalia N. Anti-biofilm properties of the faecal probiotic lactobacilli against Vibrio spp. Front Cell Infect Microbiol. 2018;8:120. https://doi.org/10.3389/fcimb.2018.00120.

35. Kaur S, Sharma P. Protease-sensitive inhibitory activity of cell-free supernatant of Lactobacillus crispatus 156 synergizes with ciprofloxacin, moxifloxacin and streptomycin against Pseudomonas aeruginosa: an in vitro study. Probiotics Antimicrob Proteins. 2015;7(2):172-80.

36. Bradford MM. A rapid and sensitive method for the quantitation of microgram quantities of protein utilizing the principle of protein-dye binding. Anal Biochem. 1976;72:248-54.

37. Laemmli UK. Cleavage of structural proteins during the assembly of the head of bacteriophage T4. Nature. 1970;227(5259):680-5.

38. Dezwaan DC, Mequio MJ, Littell JS, Allen JP, Rossbach S, Pybus V. Purification and characterization of enterocin 62-6, a two-peptide bacteriocin produced by a vaginal strain of Enterococcus faecium: potential significance in bacterial vaginosis. Microb Ecol. 2007;19:241-50.

39. Paiva AD, de Oliveira MD, de Paula SO, Baracat-Pereira MC, Breukink E, Mantovani HC. Toxicity of bovicin HC5 against mammalian cell lines and the role of cholesterol in bacteriocin activity. Microbiology. 2012;158(11):2851-8

40. Ruíz FO, Gerbaldo G, García MJ, Giordano W, Pascual L, Barberis IL. Synergistic effect between two bacteriocin-like inhibitory substances produced by lactobacilli strains with inhibitory activity for Streptococcus agalactiae. Curr Microbiol. 2012;64(4):349-56.

41. Joshi S, Bisht GS, Rawat DS, Kumar A, Kumar R, Maiti S, et al. Interaction studies of novel cell selective antimicrobial peptides with model membranes and E. coli ATCC 11775. Biochim Biophys Acta Biomembr. 2010;1798:1864-75.

42. Chopra L, Singh G, Jena KK, Sahoo DK. Sonorensin: a new bacteriocin with potential of an anti-biofilm agent and a food biopreservative. Sci Rep. 2015;5:13412. https://doi.org/10.1038/srep13412.

43. Kalab M, Yang AF, Chabot D. Conventional scanning electron microscopy of bacteria. Infocus Magazine. 2008;10:42-61.

44. McAuliffe O, Ryan MP, Ross RP, Hill C, Breeuwer P, Abee T. Lacticin 3147, a broad-spectrum bacteriocin which selectively dissipates the membrane potential. Appl Environ Microbiol. 1998;64(2):439-45.

45. Petersen PJ, Labthavikul P, Jones $\mathrm{CH}$, Bradford PA. In vitro antibacterial activities of tigecycline in combination with other antimicrobial agents determined by chequerboard and time-kill kinetic analysis. J Antimicrob Chemother. 2006;57(3):573-6.

\section{Publisher's Note}

Springer Nature remains neutral with regard to jurisdictional claims in published maps and institutional affiliations. 